\title{
Impact of Financial Intermediaries on Nigerian Economic Growth
}

\author{
Charles O. Manasseh ${ }^{1}$, Johnson I. Okoh ${ }^{2}$, Felicia C. Abada ${ }^{3}$, Jonathan E. Ogbuabor ${ }^{4}$, Felix C. Alio ${ }^{1}$, Adedoyin I. \\ Lawal $^{5}$, Ifeoma C. Nwakoby ${ }^{1}$ \& Onyinye J. Asogwa ${ }^{6}$ \\ ${ }^{1}$ Department Banking \& Finance, University of Nigeria Enugu Campus, Nsukka, Enugu State, Nigeria \\ ${ }^{2}$ Department of Financial Studies, National Open University of Nigeria, Abuja, Nigeria \\ ${ }^{3}$ School of General Studies, Social Science Unit, University of Nigeria Nsukka, Nsukka, Enugu State, Nigeria \\ ${ }^{4}$ Department of Economics, University of Nigeria, Nsukka, Nigeria \\ ${ }^{5}$ Department of Accounting \& Finance, Landmark University, Omu Aran, Nigeria \\ ${ }^{6}$ Department of Economics, Federal University, Wukari, Taraba State, Nigeria \\ Correspondence: Ifeoma C. Nwakoby, Department Banking \& Finance, University of Nigeria Enugu Campus, Enugu \\ State, Nigeria.
}

Received: June 5, 2018

doi:10.5430/ijfr.v12n1p348
Accepted: May 27, 2020

Online Published: January 22, 2021

URL: https://doi.org/10.5430/ijfr.v12n1p348

\begin{abstract}
This paper empirically investigated the impact of financial intermediation of economic growth in Nigeria. Quarterly time series data generated from the World Bank Development indicator and the Nigerian Bureau of Statistic for the periods 1994Q1 to 2018q4 were used for the analysis, and Ordinary Least Squares (OLS) regression technique was adopted for the estimation of the hypotheses. Per-capita GDP was used as a measure of economic growth, while bank deposit, bank credit and bank reserves are measures of financial intermediation. Further investigation also show that bank deposit is positively and significantly related to GDPpc, suggesting that increase in bank deposit brings about 0.244193 increases in economic growth. We further observed that bank credit impacted positively on economic growth. Though, the impact was found to be insignificant. Hence, we also found bank reserve to assert significant and positive impacted on economic growth. From the findings, we suggest for good policy reforms that may promote the efficiency and the development of bank which serve as a critical factor for economic growth in Nigeria.
\end{abstract}

Keywords: financial intermediaries, economic growth, Nigeria

\section{Introduction}

Adequate financing is partly a key determinant of economic growth. This finance is required by different organizations, individuals and economic agents to serve different purposes. However, financial services are significant for the promotion of investment and the development of infrastructural facilities. Thus, the development of efficient and functioning of financial institutions such as mortgage banks, bank of industry, agricultural development banks, deposit money banks, investment bank, and sometimes the stock exchange is imperative. The intermediary role of these financial institutions enhances the supply for funds from savers to the borrowers. Hence, before financial intermediation evolution, a system of direct or un-intermediated financing was a common practice. During thus era, economic agents who wish to invest more than their financial capacity, sort for financial assistance by borrowing from the wealthy people around them with the promise to pay in a future date. Afolabi (1998) posits that as crude as this system was, it probably satisfied the need of that time because financial requirements then were limited to such personal uses like marriages, burial ceremonies and minor commercial activities like farming. Hence, in this era, intermediation was neither necessary nor sufficient for capital formation to take place. In addition, borrowers are so confident that the intermediary role would always promote the opportunity of having sufficient funds which can be passed on to them in a friendly manner and at relatively attractive conditions. But in modem time, intermediaries do advertise for credit availability and the borrowers who are willing to access the credit can get it as long as they are credit-worthy and have viable investment that can be able to redeem the loan future date. Hence, through the intermediary role of the financial institutions, different collections of debt, equity or hybrid stake holding structures are used as a means of redistributing idle capital to potential investors, who in turn invest the fund for more job creation and the promotion of economic growth. To this effect, Afolabi (1999) pointed that of abstention from current consumption for future consumption is the relevance for economic growth. He reiterated that incomes 
not spent on consumption (i.e. net savings) are usually saved for investment purposes. Firms borrow this money (savings) for investments in capital goods which form part of economy's capital stock and therefore the economy growth. Therefore, households purchase consumer goods while firms buy capital goods for further production. In like manner, Dewett (2005) and Nwanyanwu (2010) argued that persistent increase in the aggregate output leads to changes in macroeconomic indicators such as capital formation, employment, the ratio of capital to output, technological growth and innovation among others.

However, since many banks can predict the demand for withdrawal, given the huge number of depositors, they can reduce expenditure on liquid reserves holdings which does not contribute to capital accumulation. Hence, the removal of self-financed capital investment banks may promote significant reduction in insolvency of ventures that need more liquidity (Bencivenga and Smith, 1991). Hence, the role of financial intermediation was not only limited to mobilisation of savings, but also extended to risk management, project evaluation and supervision. According to Bencivenga and Smith (1991), these issues are vital because they promote improvement in technology, innovation and economic growth. Thus, in as much as credits are obtained to meet operating expenses, it is imperative to understand that without proper evaluation of the credits; it intended objectives may not be achieved. This point was further stressed by Nwanyanwu (2010) who believed that credit assist to maintain an ideal business size. In turn, this small or an ideal business size may take advantage of economies of scale, if investors evaluate the existing risk, sectors of the economy and the price system properly before investing the funds. Other than promoting the existing business or establishing a new business, Nwanyanwu (2010) further argued credit availability may prevent an economy from total collapse in situation of adversity such as natural disaster like flood, drought and disease. Amid, banking sector is the backbone of the financial system as it stands as the only avenue to pull large saving needed for the enhancement economic growth especially in many developing economies (Afolabi, 1998). Also, evidence has shown that countries with viable financial system appear to reduce the costs of achieving potential investment, which can be achieve through risks control/reduction, cheap mobilization of savings and manage exchanges. Also, savings and allocation decision is greatly influence by intermediary role of the banks which may change the rate of long-run growth (Levine et al. 2000 and Amaechi and Arnara. 2005). However, the understanding of the relevance of the roles of bank in financial intermediation has led successive governments in Nigeria to be involve in consistent reforms in the sector to ensure that deliberate roles allocated to the banks for the attainment of various national development plans is achieved.

The debate on banks induce growth has been widely discussed. Studies by Beck et al. (2000a), and Levine et al. (2000) reiterated that efficient and active banks accelerate economic growth. Hence, viable financial institutions are necessary to promotes economy activities. An efficient and highly intermediation system is essential for a healthy economy because, the activity of banks affects every citizen directly or indirectly in the economy (Ngwu, 2006). According to Uremadu (2000), large-scale production and specialization of labour can only function if an efficient and highly developed financial system exists for paying for goods and services, whether they are needed in production or are offered for sale. Also, business organizations can easily purchase capital goods, such as machinery and equipment only if the necessary institutions, instruments and procedures have been established for making savings available for such investments. In the absence of banks, too much investment is self-financed which results to the slow cycle of production (Bencivenga and Smith, 1991). This may result to the problems of long delays between investment spending and receipts of profit from capital. Thus, efficient intermediary role of the banking system helps an economy to cut dawn the portion of its savings held in the form of unproductive liquid assets and to avoid misallocations of capital. In view of the above discussion, this study empirically investigates the extent to which Nigerian deposit money banks intermediary role impacted on economic growth. The remaining part of the study includes the theoretical and empirical review of literature discussed in section two. The discussion of theoretical framework and method of estimation is presented in section three, while section four shows data presentation and analyses of the findings. Hence, in section five we conclude and present policy recommendation from the findings.

\section{Theoretical and Empirical Review of Literature}

The theoretical argument on the relationship between financial intermediation and economic growth has continued to gain prominence in the literature. While believe that efficient financial system promote the intermediary role of the banks which in turn project growth, other pointed that economic growth granger causes financial intermediation. This issue has remains contentious amongst economist, researchers and policymakers as well. Hence, Solow and Swan (1956) introduced neo-classical theory which postulated that economic growth is dependent on labour, capital and technology. Their premise remains that the acquisition of long term assets such as machineries, real estate and manufacturing can only boost economic growth in a short term. They believed that consistent increase in the ratio of 
capital to labour may result to more availability of capital for each worker while the marginal output of a unit increase in capital declined and thus, after a while the economy will return to long term growth path. Hence, their strong hold is that an economy can only be in a "steady-state" when capital, output and labour grows at the same rate with output per-worker as well as capital per-worker remains constant. This implies that long term growth requires improvement in capital, productivity of labour and its supply. Hence, improvement in productivity is considered exogenous indicating its dependent capital investment. Though, they noted that the rate of changes in technology explain the variation economic growth between developing and developed economies. However, there is no doubt that neo-classical growth theory provides the insight on what may seem to be the determinants of growth, but that does not mean it's free from criticism. Romer (1986) and Lucas (1988) disagree with the postulate of neo-classical growth theory, which led to the emergence of endogenous growth or new growth theory developed in the 1980s. Consequently, endogenous growth theory becomes the body of literature that challenged the assumption of the Solow theory. Furthermore, endogenous growth theory pointed that policy measures may impact long run growth rate, and that long run growth rate is determined by the variables in the model and not exogenous rate of technological progress as asserted Solow and Swan (1956). Supporting endogenous growth theory, Jhingan (2006) argued that rate of investment, capital stock size and human capital stock determines technical progress and not the reverse.

Using the endogenous growth theory, Nnanna et al. (2004) studies the relationship between financial development and economic growth. In this study they investigated the impact of financial intermediation efficiency, social marginal productivity of capital and private savings rate on economic growth. Hence, their findings suggest that economic growth is significantly promoted y the three components of financial development measures according to the study. In addition, study by Greenwood and Jovanovic (1990) revealed that financial intermediation brings together funds and raises average return to capital. They further argued that economic growth is a forward looking activity which based largely on investment and other growth determinants. Thus, maintaining that investor's expectation derives investment regarding future returns. Other studies such as Odeniran and Udeaja (2010), Adamopoulos and Dristsakis (2000), Ray (2013) and Shan and Jianhong (2008) also support the evidence that financial development promotes economic growth. They are of the opinion that a developed financial system always exhibit high level of intermediary role. In a similar study in Turkey, Pinar and Damar (2006) found a negative relationship. They argued that the evidence on the inverse relationship could be caused by high level of distortion in the structure of the system towards government finance. In addition, in a cross-country study for 71 developing countries, and in Nigeria, King and Levine (1993) and, Odedokun (1998) respectively found significant and positive relationship between financial intermediation and economic growth.

Continuing the argument in the association between financial intermediary and economic growth, Hao (2006) opines that financial intermediation has a causal effect and positively impacted on household savings and substitution of loans for state budget appropriations. Also, using OLS estimation techniques, Nwite (2014) shows that interest rate margin and credit to private sector significantly impact on economic development in Nigeria. Thus, he concluded that there is evidence of significant and positive effect of financial intermediation on economic growth in Nigeria. Adopting vector error correction model, Tonye and Andabai (2014) found the existence of a long-run impact of financial intermediation on economic growth. However, Moutie, Ngouhouo and Kamajou (2015) investigation on the influence of financial intermediation on economic growth in Cameroon for the periods 1977 to 2006, revealed a positive and non-significant impact on economic growth. Also, there was no evidence of causal relationship between FI and economic growth. In addition, Elumelu (2002) revealed that the contribution of the financial sector to growth increased after the financial deregulation and even exceed the share of manufacturing sector to economic growth. The study of Faly (2004) is in it total agreement with this finding, he found out that many of the new banks were not interested in intermediating funds from depositors to lenders but rather made quick profits from the arbitrage and other rent-seeking activities.

In addition, extending the role of financial intermediation, Dumani et al. (2017) show that loans and advance to agriculture, fisheries forestry, manufacturing sector and small scale enterprises significantly influence on economic growth in Nigeria. In like manner, Shittu (2012) study on the impact of financial intermediation on economic growth in Nigeria revealed that broad money (M2) was more influential on economic growth than credit to the private sector. But the studies by Agbada and Osuji (2013) on the relationship between financial intermediation and output show that loans and advances have a negative and insignificant relationship with output. Other studies in Nigeria, Jordan and Uganda such as Haruna (2012), Idries (2010) and Beck and Hessen (2006) studies also found evidence that financial intermediation does not impact economic growth. Adekunle et al. (2013) study on financial development and economic growth in Nigeria also revealed that measures of financial development are negatively correlated with growth. 


\section{Theoretical Framework and Methodology}

The theoretical underpinning of this study is anchored on endogenous growth theory. This theory holds that relevant policy measures are key determinants of long-run growth rate of an economy, which also suggest that long-run growth rate is determined by variables within the model, and not exogenously determined by technological progress as postulated by neo-classical growth Theory. However, this study adopted Ordinary Least Square (OLS) technique to estimate the relationship between financial intermediation and economic growth. The rationale behind the choice the technique was based on the premise that OLS is assumed to be the best linear unbiased estimator (Uremadu, 2002). It also has minimum variance (Anyanwu, 2000). Using data over the period 1994q1 - 2018q4, and in tune with the model adopted by Ujah (2010), Barro (1991) and Levine et al. (2000), GDPpc is used as proxy for economic growth regressed on variety of independent variables while holding constant other factors that may affect economic growth.

$$
Y=\beta_{0}+\beta_{1} X+\beta_{2} X+\mu
$$

Where: $\mathrm{Y}$ represent dependent variable, $\mathrm{X}$; is the independent variables. $\beta_{1}$ and $\beta_{2}$ are the coefficients of $\mathrm{X}$, while $\beta_{0}$ and $\mu$ are constant and error term respectively. In specifying the models for this study, the following abbreviations are used to denote respective variables. GDPpc stand for per-capita gross domestic product and it is used as a proxy for economic growth. Hence, economic growth measures the persistence change in economic variables. This variable is used to determine availability of natural resources, the rate of capital formation, capital-output ratio, technological progress, dynamic entrepreneurship and other factors. In like manner, $D M B D$ stand for deposit money bank deposits which captured the amount of money deposit by the depositor or saver. It can be savings, current or fixed deposit. The inclusion of the variable is to know the total money deposited in the commercial bank. $D M B C$ captures the total amount of credits mobilized. Deposit Money Bank Liquid Reserve $(D M B L R)$ is include to know the total cash reserve that is easily asses by both the savers and the lenders and its influence on economic growth. Government Expenditure $(G E)$ measures the total money spent by the federal government through the central bank to the commercial bank. The variable explains the total amount of money the central bank used to control the commercial bank so that the savers and lenders can easily get cash when they are in need of it. Thus, to investigate if financial intermediation has significant impact on economic growth, eqn. 2 as shown below is adopted.

$$
\mathrm{RGDPC}=\beta_{0}+\beta_{1} \mathrm{DMBD}+\beta_{2} \mathrm{DMBC}+\beta_{3} \mathrm{DMBLR}+\beta_{4} \mathrm{GE}+\mu
$$

\section{Data Presentation and Analysis}

Table 1. Unit root test

\begin{tabular}{llllll}
\hline Variables & $5 \%$ Critical value & Level & $1^{\text {st }}$ Diff & $2^{\text {nd }}$ Diff & Order \\
\hline GDPpc & -2.901217 & 0.263075 & $-2.698313^{*}$ & $-6.328120^{* *}$ & $\mathrm{I}(2)$ \\
\hline DMBD & -2.899619 & -1.110293 & $-2.671931^{*}$ & $-11.06941^{* *}$ & $\mathrm{I}(2)$ \\
\hline DMBC & -2.899619 & -0.814600 & $-2.726857^{*}$ & $-10.64298^{* *}$ & $\mathrm{I}(2)$ \\
\hline DMBLR & -2.903566 & 1.162931 & $2.205885^{*}$ & $-9.381362^{* *}$ & $\mathrm{I}(2)$ \\
\hline GE & -2.903566 & -0.746073 & $-2.651932^{*}$ & $-5.951976^{* *}$ & $\mathrm{I}(2)$ \\
\hline
\end{tabular}

From the above unit root test, it can seen that all the variables are integrated of order two I(2). That is at level and first difference the variables has a unit root, at the second difference it became stationary, these will be use to run the regression and test for the different hypotheses.

Table 2. Co-integration test

\begin{tabular}{lllll}
\hline Hypothesized & Eigen value & Trace-Statistics & Critical value $(0.05)$ & Prob $^{* *}$ \\
\hline$r 0$ & 0.306126 & 75.79966 & 69.81889 & 0.0154 \\
\hline$r 1$ & 0.251711 & 47.65890 & 47.85613 & 0.0522 \\
\hline$r 2$ & 0.167413 & 25.33152 & 29.79707 & 0.1499 \\
\hline$r 3$ & 0.124820 & 11.22377 & 15.49471 & 0.1981 \\
\hline$r 4$ & 0.012361 & 0.957731 & 3.841466 & 0.3278 \\
\hline
\end{tabular}


Considering Table 2 above, there is a long run relationship between dependent variable and the independent variables within the period under review.

Table 3 shown below presented the estimated impact of financial intermediation on economic growth in Nigeria. The coefficient of determinant $\left(\mathrm{R}^{2}\right)$ as used to measure the success of the regression in predicting the value of the dependent variables within the sample and test for the goodness of fit, which is consider high in this study over 66\%; the adjusted R-square, Durbin-Watson statistic and F-statistics are significant. The result also shows no serial or auto-correlation. A close examination on the results reveals that some signs were not in line with the apriori expectation. From the result, $D M B D$ has a significant and positive impact on economic growth. The findings suggest that an increase in deposit money bank deposit $(D M B D)$ lead to 0.244193 increase in economic growth. Also, we find a positive and significant relationship between $D M B L R$ and economic growth. Thus, this shows that a change in deposit money bank liquid reserve (DMBLR) and Government expenditure $(G E)$ could lead to 0.212037 increases in economic growth. However, the findings of this study is consistent with the postulate of endogenous growth theory which argued that relevant policy measures are key determinants of long-run growth rate of an economy, and that long-run growth rate is determined by variables within the model, and not exogenously determined by technological progress as postulated by neo-classical growth. Also our study's findings is consistent with Hao (2006), Nwite (2014), Odeniran and Udeaja (2010), Ray (2013), Dumani et al. (2017), Shan and Jianhong (2008), Nnanna et al. (2004) and Dristsakis (2000), but contradicted evidence from Agbada and Osuji (2013), Haruna (2012), Idries (2010), Beck and Hessen (2006) and Adekunle et al. (2013)

Table 3. Regression result

\begin{tabular}{lllll}
\hline Variable & Co-efficient & Std. Error & t-Statistics & Prob \\
\hline $\mathrm{C}$ & -0.001157 & 0.003345 & -0.346002 & 0.7303 \\
\hline $\mathrm{D}(\mathrm{DMBD})$ & 0.244193 & 0.024225 & 10.08007 & 0.0000 \\
\hline $\mathrm{D}(\mathrm{DMBC})$ & 0.008104 & 0.016189 & 0.500586 & 0.6182 \\
\hline $\mathrm{D}$ (DMBLR) & 0.212037 & 0.025652 & 8.265839 & 0.0000 \\
\hline $\mathrm{D}$ (DGE) & 0.008917 & 0.016865 & 0.258686 & 0.5986 \\
\hline R-squared & 0.661570 & & & \\
\hline Adjusted R-square & 0.043026 & & & \\
\hline F-statistics & 35.67548 & & & \\
\hline Durbin-Watson stat & 2.438971 & & & \\
\hline
\end{tabular}

\section{Conclusions and Policy Recommendation}

Using Ordinary least square techniques, we examined the impact of financial intermediation on economic growth. The study measures economic growth with per-capita GDP, while financial intermediation was proxied with bank deposit (MBD), bank credit (MBC) and liquid bank reserves (MBLR). The influence of government was controlled by looking at the impact of government expenditure (GE) on economic growth. Hence, from the research findings, the empirical evidence from the study shows that found bank reserve to assert significant and positive impacted on economic growth. This implies that increase in bank reserve will bring about 0.212037 increases in economic growth. Therefore, policies that may encourage increase in the reserves of the banks in Nigeria should be implemented. We also observed that that bank credit impacted positively on economic growth. Though, the impact was found to be insignificant. The outcome of this finding may be as a result of the nature of the data. Further investigation also show that bank deposit is positively and significantly related to $G D P p c$, suggesting that increase in bank deposit brings about 0.244193 increases in economic growth. From the findings, we inferred that financial intermediation significantly impacted on economic growth and suggest for good policy reforms that may promote the efficiency and the development of banks should be implemented to boost economic growth in Nigeria. In addition, Nigerian Banks should shore up their liquid reserves to further enhance stability of their operations. The study further recommended that the apex bank - Central Bank of Nigeria (CBN) should check the activities of deposit money banks from possessing excess liquidity to ensure the prevention of inflation in the economy, and a viable regulatory frame work that will enable the financial institutions to channel their resources to the most key sector of the economy. 


\section{References}

Acha, I. A. (2011). Financial intermediation by banks and economic growth in Nigeria, 1990-2008. Journal of Economics and Sustainable Development, 2(4), 129-139.

Adamopoulos, A., \& Dritsakis, N. (2000). Financial development and economic growth in Greece: An empirical investigation with granger causality analysis. Working paper, 1-24.

Adekanve, F. (1986). The elements of banking in Nigeria. F and A Publishers Limited.

Adekunle, O., Salami, G. O., \& Adedipe, O. A. (2013). Impact of financial sector development on Nigerian economic growth. American Journal of Business and Management, 2(4), 347-365.

Ademu, W. A. (2006). The informal sector and employment generation in Nigeria: The role of credit in employment generation in Nigeria. Selected Papers for the 2006 Annual Conference of the Nigerian Economic Society.

Adeniyi, O. M. (2006). Bank credit and economic development in Nigeria: A case study of deposit money banks. Jos: University of Jos.

Afolabi, L. (1998). Monetary economics. Lagos: Peny Barr Limited.

Agbada, A. O., \& Osuji, C. C. (2013). An empirical analysis of trends in financial intermediation and output in Nigeria. Global Journal of Management and Business Research, 13(9), 115-125.

Amaechi, A. F., \& Arnara, T. C. (2005). Manual of research methodology and thesis writing. Aba: Ker Experts Book Limited.

Anyanwu, A. (2000). Research methodology in business and social sciences. Owerri: Canunn Publishers Nigeria Limited.

Arestis, P., \& Demetriades, P. O. (1997). Financial development and economic growth: Assessing the evidence. The Economic Journal, 107(442), 783-799. https://doi.org/10.1111/j.1468-0297.1997.tb00043.x

Barro, R. J. (1991). Economic growth in a gross section of countries. The Quarterly Journal of Economics, 52(2), 407-443. https://doi.org/10.2307/2937943

Beck, T., \& Hesse, H. (2006). Bank efficiency, ownership and market structure: Why is interest rate spread so high in Uganda?. University of Oxford, discussion Paper Series No 277. https://doi.org/10.1596/1813-9450-4027

Beck, T., \& Levine, R. (2002). Industry growth and capital allocation: Does having a market or a bank-based system matter?. Journal of Financial Economics, 64, 147-180. https://doi.org/10.1016/S0304-405X(02)00074-0

Beck, T., Levine, R., \& Loayza, N. (2000a). Finance and the sources of growth. Journal of Financial Economics, 58, 261-300. https://doi.org/10.1016/S0304-405X(00)00072-6

Bekarert, G. (1996). Market integration and investment barriers in emerging stock market. The World Bank Economic Review, 9(75), 107-185. https://doi.org/10.1093/wber/9.1.75

Bencivenga, V. R., \& Smith, B. D. (1991). Financial intermediation and endogenous growth. Review of Economic Studies, 195, 209. https://doi.org/10.2307/2297964

Dedokun, M. (1998). Financial intermediation and economic growth in developing countries. Journal of Economic Studies, 25(2-3), 203-222. https://doi.org/10.1108/01443589810215351

Demetriades, P., \& Andrianova, S. (2004). Finance and growth, what we know and what we need to know. University of Leicester. https://doi.org/10.1057/9780230374270_2

Dernetriades, P., \& Luintel, K. (1996). Financial development economic growth and banking sector controls: Evidence from India. The Economic Journal, 106, 359-374. https://doi.org/10.2307/2235252

Dewett, K. K. (2005). Modern economic theory. New Dethi: Shyan Lal Charitable Trust.

Diamond, D. (1984). Financial intermediation and delegated monitoring. Review of Economic Studies, 51, 393-414. https://doi.org/10.2307/2297430

Diamond, D., \& Dybvig, P. (1983). Bank runs, deposit insurance and liquidity. Journal of Political Economy, 85(19), $1-206$.

Dumani, M., Ekokemi, T. T., Johnny, N., \& Krokeme, O. (2017). Impact of financial intermediation on economic growth in Nigeria: A disaggregate approach. Journal of Economics and Sustainable Development, 8(22), 9-14. https://doi.org/10.1086/261155 
Ekezie, F. S. (1997). The elements of banking. Onitsha: Aflicana Fep Publisher Limited.

Fry, M. J. (1988). Money, interest and banking in economic development. London: University Press.

Greenwood, J., \& Jovanovic, B. (1990). Financial development, growth and the distribution of income. Journal of Political Economy, 98, 1076-1107. https://doi.org/10.1086/261720

Greenwood, J., \& Smith, B. (1996). Financial market, in development and the development of financial markets. Journal of Economic Dynamics and Control, 21, 145-181. https://doi.org/10.1016/0165-1889(95)00928-0

Gurley, J., \& Shaw, E. (1967). Financial structure and economic development. Economic Development and Cultural Change, 15(3), 257-268. https://doi.org/10.1086/450226

Hao, C. (2006). Development of financial intermediation and economic growth: the Chinese experience. China Economic Review, 17(4), 347-362. https://doi.org/10.1016/j.chieco.2006.01.001

Haruna, M. A. (2012). Determinants of cost of financial intermediation in Nigeria pre-consolidated banking sector. International Journal of Advanced research in Management and Social Sciences, 1(2), 180-194.

Idries, M. A. (2010). Cost of financial intermediation in the banking sector of Jordan. International Research Journal of Finance and Economics, (56), 7-21.

Jhingan, M. L. (2004). Money banking, international trade and public finance. Journal of Applied Econometrics and International Developmont, 3, 137-150.

Khaled, A., \& Sainer, A. (2006). Financial development and economic growth: a new empirical evidence from the mena countries (pp.1989-2001).

King, R. G., \& Levine, R. (1993). Schumpeter might be right. Quarter Journal of Economics, 108(3), 717-737. https://doi.org/10.2307/2118406

King, R. G., \& Levine, R. (1993b). Finance, entrepreneurship and growth: theory and evidence. Journal of Monetary Economics, 32, 513-542. https://doi.org/10.1016/0304-3932(93)90028-E

King, R. G., \& Levine, R. (1993a). Finance and Growth: Schumpeter Might be Right. Quarterly Journal of Economics, 108, 117-738.

King, R., \& Levine, R. (1993). Finance and growth: Schumpeter might be right. The Quarterly Journal of Economics, 108, 681-737. https://doi.org/10.2307/2118406

Levine, R. (1991). Stock markets, growth and tax policy. The Journal of Finance, 46(4), 1445-1465. https://doi.org/10.1111/j.1540-6261.1991.tb04625.x

Levine, R. (1997). Financial development and economic growth: views and Agenda. The Journal of Economic Literature, 35(2), 688-726.

Levine, R., \& Zervos, S. (1998). What we have learnt about policy and growth from cross-country regressions. The American Economic Review, 83(2), 426-440.

Loayza, N., \& Beck, T. (2002). Financial intermediation and economic growth: causes and causality. Journal of Monetary Economics, 46, 31-77. https://doi.org/10.1016/S0304-3932(00)00017-9

Lucas, R. E. (1988). On the mechanics of economic development. Journal of Monetary Economics, 22, 3-42. https://doi.org/10.1016/0304-3932(88)90168-7

McKinnon, R. (1973). Money and capital in economic development. Washington: The Brookings Institute.

Moutie, G., Ngouhouo, I., \& Kamajou, F. (2015). Effect of financial intermediation on economic growth in Cameroon. International Journal of Management Science, Research Academy of Social Science, 5(9), 639-649.

Ngwu, T. C. (2006). Bank management and Nigeria's economic growth. Nigerian Journal of Integrated Financial Science, 1, 18-27.

Nnanna, O. J. (2004). Financial sector development and economic growth in Nigeria: an empirical investigation. Economic and Financial Review, 42(3), 1-17.

Nnanna, O. J., Englama, A., \& Odoko, F. O. (2004). Financial markets in Nigeria. Abuja: Kas Arts Service.

Nwankwo, G. O. (1991). Bank management, principles and practice. Lagos: Malthouse Press Limited.

Nwanyanwu, O. J. (2010). An analysis of bank credit on the Nigeria economic growth (1992-2008). Jos Journal of Economics, 4, 43-58. 
Nwite, S. C. (2014). Determinants of financial intermediation and its implications on economic growth in Nigeria. British Journal of Marketing Studies, 3(9), 49-56.

Nwude, E. C. (2004). Basic principles of financial management: A first course. Enugu: Chuke Nwabude Nigeria.

Nzotta, S. M. (1999). Money, banking and finance. Owerri: International Educational Books and Publishers.

Ochejele, J. J. (2007). Economic analysis. Jos: Ichejum Press.

Odeniran, O. S., \& Udeaja, A. E. (2010). Financial sector development and economic growth: empirical evidence from Nigeria. Central Bank of Nigeria Economic and Financial Review, 91-124.

Ogar, S. B., Nkamere, S. B., \& Offiong, C. (2014). Commercial bank credit and its contributions on manufacturing sector in Nigeria. Research Journal of Finance and Accounting, 2(22), 79-100.

Ogege, S., \& Shiro, A. A. (2013). Does depositing money in bank impact on economic growth? Evidence from Nigeria. African Journal of Business Management, 7(3), 196-205.

Oiji, J. (1996). Elements of banking. Enugu: Rock Communications Limited.

Olson, O. J. (1996). Big bills left on the sidewalks: why small nations are rich and others poor. The Journal of Economic Perspectives, 10(2), 1-24. https://doi.org/10.1257/jep.10.2.3

Oluitan, R. (2010). Bank credit and economic growth: The Nigerian experience. A Presentation at the 7th AFE Conference in Greece, July.

Onwurnere, J. U. (2009). Business and economic research methods. Enugu: Vougasen Limited.

Osuala, A. E. (1991). Introduction to research methodology. Onitsha: Africana FEP Publishers Ltd. Oxford University Press.

Patrick, H. T. (1966). Financial development and economic growth in underdeveloped countries. Economic Development and Cultural Change, 14, 174-189. https://doi.org/10.1086/450153

Pinar, A., \& Damar, E. (2006). Financial sector deepening and economic growth. Working Paper, pp.1-17.

Ray, S. (2013). Does financial development promote economic growth in India?. International Journal of Economic Practices and Theories, 140-151.

Robbrnson, J. (1952). The generalization of the general theory. In The rate of interest and other essays (pp. 67-146). London: Macmillan.

Romer, P. M. (1986). Increasing returns and long-run growth. Journal of Political Economy, 94, 1002-1037. https://doi.org/10.1086/261420

Schumpeter, J. A. (1934). The theory of economic development Cambridge. Mass: Harvard University Press.

Shan, J., \& Jianhong, Q. (2006). Does financial development lead economic growth? The case of China. Annals of Economics and Finance, 1, 231-250.

Shaw, F. S. (1973). Financial deepening in economic development. New York.

Shittu, A. I. (2012). Financial intermediation and economic growth in Nigeria. British Journal of Arts and Social Sciences, 4(2).

Spencer, H. M. (1977). Contemporary macroeconomics (3rd ed.). York Worth Publishers.

Thingan, M. L. (2006). Economics of development and planning. New Delhi: Vrinda Publications (P) Ltd.

Tonye, O., \& Andabai, P. (2014). Financial intermediation and economic growth in Nigeria. Mediterranean Journal of Social Sciences, 5(7), 12-25.

Uche, C. U. (2001). The theory of regulation: a review article. Journal of Financial Regulation and Compliance, 9(1), 67-80. https://doi.org/10.1108/eb025063

Uremadu, S. O. (2000). Bank Management. Basic Issues in Money, Bank Lending and Credit Administration. Benin City: Mindex Publishing Company.

Uremadu, S. O. (2002). Academic Research Methods: As Applied to Accounting. Banking and Finance, Business Management and Economics. Benin City: Mindex Publishing Company Limited.

Uremadu, S. O. (2012). Bank Capital Structure, Liquidity and Profitability, Evidence from the Nigerian Banking System. International Journal of Academic Research in accounting, Finance and Management Sciences, 2(1), 
98-113.

Uzoaga, W. O. (1981). Money and Banking in Nigeria. Enugu, Fourth Dimension Publishers.

Zakari, Z. (2008). The Level of Economic Development and the Impact of Finacial Structure on Economic Growth: Evidence from Dynamic Panel analyses. Asian Academy of Management Journal of Accounting and Finance, $3(2), 1-42$.

\section{Copyrights}

Copyright for this article is retained by the author(s), with first publication rights granted to the journal.

This is an open-access article distributed under the terms and conditions of the Creative Commons Attribution license (http://creativecommons.org/licenses/by/4.0/). 